\title{
Factors Affecting Society Intention to Use the Equity Crowdfunding Platform
}

\author{
Fauzan Nasafi ${ }^{1}$, Firman Pangemanan ${ }^{2}$, Sfenrianto $^{3}$, Gunawan Wang ${ }^{4}$ \\ Information Systems Management Department,BINUS Graduate Program - Master of Information Systems, \\ Bina Nusantara University, Jakarta, Indonesia, 11480. \\ 17auzan.nasafi@binus.ac.id; ${ }^{2}$ firman.pangemanan@binus.ac.id; ${ }^{3}$ sfenrianto@binus.edu; ${ }^{4}$ gwang@ binus.edu.
}

\begin{abstract}
Crowdfunding simply is funding from crowd or many sources or parties, can be started from collecting fund from families and friends then expanded to society through internet. In Digital Business Era, Indonesian urban society have not utilized equity crowdfunding to its maximum. Therefore, this research expected to discover the Factors Affecting Jakarta's Society Intention to Use the Equity Crowdfunding Platform in Indonesia. This research collected data of 100 Jakarta's citizen randomly. Data Analysis using the combination of 2 research model from previous equity crowdfunding research. This research proved that the factors affecting Jakarta's society intention to use the equity crowdfunding platform in Indonesia are The Success of Equity Crowdfunding Platform Campaign and The Mature of Project Stage.
\end{abstract}

Key words: Equity Crowdfunding, Intention to use, Digital Business, Equity Crowdfunding Platform and Project Stage

\section{INTRODUCTION}

Funding is one of important components in establish a firm. New firm will face difficulties in collecting external fund during the establishment period [1]. To achieve that funding, firm will meet challenges to affect the investor to commit for the funding [2]. That challenges urge the emerge of new methods to do the funding.

One of the funding methods that developed in digital business era is through crowdfunding. Crowdsourcing described as a group of people collecting their assets, resources, knowledge as well as their skills [3]. While Crowdfunding is an activity that involve an open call, mostly through internet, providing financial resources in many forms such as donation, as repayment of goods or as an initiative for certain target [1]. Thus, the crowdfunding in Indonesia's digital business need to be develop more.

This time, number of Indonesian crowdfunding compare with other Asian countries such as India and Malaysia are quite competitive [4]. The platform development funded by crowdfunding also will affecting the development of the Small Micro Medium Enterprises (UMKM) in Indonesia.

\section{LITERATURE REVIEW}

\section{A. Crowdfunding Methods}

Crowdfunding is a method for gathering small contributors, through online platforms, to funding the companies [5]. Funding through the Crowdfunding method is urgently needed by digital business companies.
Mollick(2014) said that Crowdfunding is a novel method for funding a variety of new ventures, allowing individual founders of for-profit, cultural, or social projects to request funding from many individuals, often in return for future products or equity [11].

Agrawal (2013) mentioned that investment patterns over time are independent of geographic distance between entrepreneur and investor after controlling for the entrepreneur's online social network. That economic frictions relate of investing early-stage projects over long distance can be reduce by online mechanisms [12].

There are two types of crowdfunding based on the relationship between individuals who provide financial resources (crowd funders) and recipients (campaign owners), namely non-financial crowdfunding and financial crowdfunding [6]. Financial crowdfunding is an investor who contributes to individuals, businesses or entrepreneurs who offer financial returns within a certain period of time to these investors.

Based on these two types of crowdfunding, Massolution (2015) in [6] dividing it into 5 crowdfunding models:

1) Non-Financial Crowdfunding: Donation Based Crowdfunding, is Crowdfunding which starts with general information aimed at charity in which the donation is given without expecting financial return from the donation. Owners of this crowdfunding campaign usually raise funds for independent projects, for example, an NGO launches a campaign to build schools for children in rural areas. Provided that as long as there is no expectation or legal obligation to return the money that has been transferred and is considered as a donation or gift, therefore the crowdfunding model is referred to as a donation based.

2)Non-Financial Crowdfunding: Rewards Based Crowdfunding, is a Crowdfunding with crowd funders who provide funds to support the campaign with a return or profit including products that will be produced with the funds collected during the campaign. For an example a music band that wants to record an album, can request funding for studio rental fees by offering copies of the albums signed by all members of the band to those who contribute to the crowdfunding campaign, therefore the crowdfunding model is referred to as rewards-based crowdfunding.

3)Financial Crowdfunding: Lending Based Crowdfunding, is a Crowdfunding with investors who receive debt instruments that specifically contain future payment terms. Which is basically the obligation of the campaign 
Fauzan Nasafi et al., International Journal of Emerging Trends in Engineering Research, 8(6), June 2020, 2245 - 2248

owner to repay funds provided by investors, which usually consists of principal plus a fixed interest rate. Examples of crowdfunding are peer-to-peer (P2P) and peer to business (P2B) lending (including SME lending).

4)Financial Crowdfunding: Equity Based Crowdfunding, is a Crowdfunding with investors who receive equity instruments that provide part ownership or part of future income. In this model, the returns earned by crowd funder are related to the success of the business they invest in the future. Therefore equity-based crowdfunding presents the potential for greater returns, because the value of equity can increase according to business success in the future. But it can also present a big risk if there is a failure in the business in the future.

5)Financial Crowdfunding: Royalty Based Crowdfunding, is Crowdfunding with crowd funders who accept contracts with a guarantee that crowd funders will receive a fixed percentage or amount of revenue received by the company that is held by the owner of the campaign. This is generally related to the interest of royalties from the company's intellectual property and the income it generates. Profits here have the potential not to be limited to fixed interest rates, but companies with intellectual property that were initially funded can stop operating or sell them to competing companies or acquire. This makes the royalty-based model more complex and less commonly used. Nonetheless, this model provides an interesting example of innovation that has emerged in the crowdfunding market.

\section{B. Previous Research}

This research then reexamined previous research variables [7] [8]. There is a difference between this research and the two previous research, namely the research approach, research location and research variables. On the [7] research, research conducted on equity crowd funding in China while research [8] conduct on equity crowdfunding in United Kingdom.

Specifically, for research variables, this research combines several variables that exist in the two previous research as well as adding success equity crowdfunding campaign variables. The variables chosen from the two previous research are equity retention, firm age, the economic potential of the firm, success equity crowd funding campaign, minimum initial investment amount and mature project stage

On the [8] research conducted by Correia, Sousa and Brandao in 2019, there was no evidence of economic potential of firm factors affecting the success of the equity crowd funding campaign. The relevance of firm age factors to the success of equity crowdfunding campaigns is inconclusive.

Meanwhile, on the [7] research conducted by $\mathrm{Li}$, Cao and Zhao in 2018, the minimum initial investment amount factor causes the possibility of more investors participating in the project. As for the mature project stage factor, it influences the willingness to invest by investors

The last factor that is considered to influence people's decisions in using the equity crowdfunding platform is the success equity crowdfunding platform campaign. This factor is an additional factor from the combination of the two variables of previous studies.

Importantly, participation may have a significant effect on the economy by encouraging a more diverse set of people to start small entrepreneurial ventures, influencing the type of ideas that are introduced into the world, and the use disposable income to support these ventures [13].

Agrawal (2013) conclude that crowdfunding platforms will compete on variations in market design, employing different rules for engagement and tools for reputation, crowd due diligence, and provision point mechanisms, among others, this will discover new markets for trusted intermediaries to emerge [14].

\section{RESEARCH METHOD}

This research was conducted quantitatively using the SEM (Structural Equation Modeling) method. The population is the Jakarta's society. Data from this study were obtained through distributed the questionnaires to the Jakarta's society. The distribution of this questionnaire was conducted on 16th to 19th August 2019 and the data collected by online questionnaire from 100 respondents.

\section{A. Research Model}

The conceptual framework that illustrates the direction of the research hypothesis (Figure 1) is as follows:

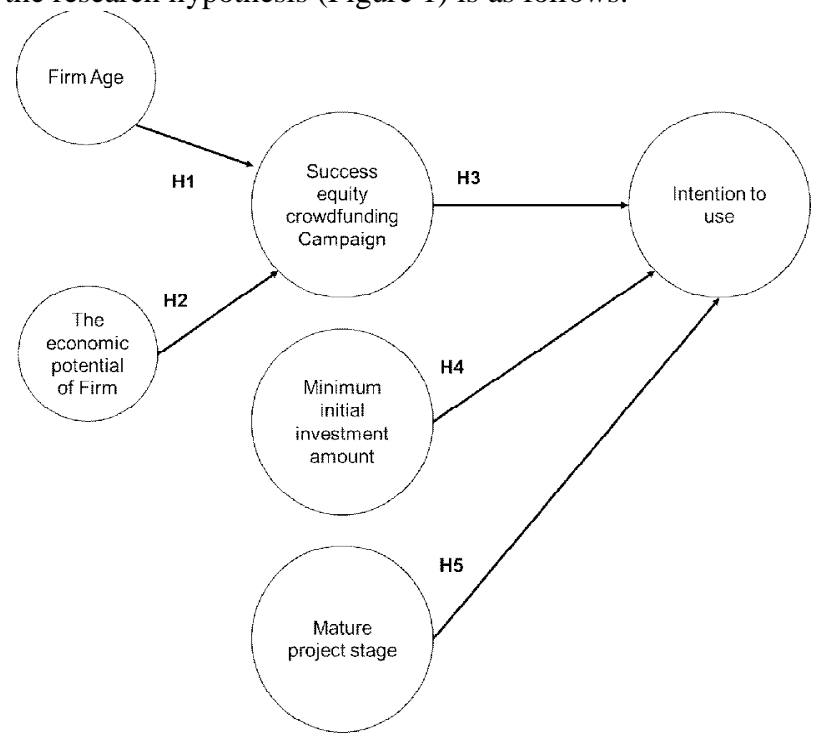

Figure 1:Research Model

The conceptual framework above was developed to describe what really affects people to use the equity crowdfunding platform.

\section{B. Variables and Indicators}

Based on the explanation of subchapter II, Table 1 explains the indicators that affect the research variables.

Table 1: Variables and Indicators

\begin{tabular}{|c|c|c|}
\hline No & Variables & Indicators \\
\hline 1 & $\begin{array}{c}\text { Economic } \\
\text { Potential of } \\
\text { Firm }\end{array}$ & $\begin{array}{c}\text { The Equity crowdfunding platform with } \\
\text { companies that will be funded has a good profit, } \\
\text { affecting you to use an equity crowdfunding } \\
\text { platform }\end{array}$ \\
\hline 2 & & $\begin{array}{c}\text { The Equity crowdfunding platform with } \\
\text { companies that will be funded has a big market, } \\
\text { affecting you to use an equity crowdfunding } \\
\text { platform }\end{array}$ \\
\hline 3 & & $\begin{array}{c}\text { The Equity crowdfunding platform with } \\
\text { companies that will be funded has a product used } \\
\text { by many people, affecting you to use an equity }\end{array}$ \\
\hline
\end{tabular}


Fauzan Nasafi et al., International Journal of Emerging Trends in Engineering Research, 8(6), June 2020, 2245 - 2248

\begin{tabular}{|c|c|c|}
\hline & & crowdfunding platform \\
\hline 4 & Firm Age & $\begin{array}{c}\text { The Equity crowdfunding platform with } \\
\text { companies that will be funded that have long been } \\
\text { established, affecting you to use an equity } \\
\text { crowdfunding platform. }\end{array}$ \\
\hline 5 & & $\begin{array}{c}\text { The Equity crowdfunding platform with } \\
\text { companies that will be funded there are a startup } \\
\text { companies, affecting you to use an equity } \\
\text { crowdfunding platform }\end{array}$ \\
\hline 6 & $\begin{array}{l}\text { Minimum } \\
\text { Initial } \\
\text { Investment } \\
\text { Amount }\end{array}$ & $\begin{array}{l}\text { The initial investment amount affecting you to use } \\
\text { an equity crowdfunding platform }\end{array}$ \\
\hline 7 & & $\begin{array}{l}\text { The less amount of initial investment affecting } \\
\text { you to use an equity crowdfunding platform }\end{array}$ \\
\hline 8 & & $\begin{array}{c}\text { Larger initial investment amount assures you that } \\
\text { the equity crowdfunding platform is more } \\
\text { bonafide }\end{array}$ \\
\hline 9 & $\begin{array}{l}\text { Mature } \\
\text { Project } \\
\text { Stage }\end{array}$ & $\begin{array}{l}\text { The Equity crowdfunding platform with } \\
\text { companies that will be funded, are still in the stage } \\
\text { of developing their products and have not sell } \\
\text { them to the market, affecting you to use an equity } \\
\text { crowdfunding platform }\end{array}$ \\
\hline
\end{tabular}

\begin{tabular}{|c|c|c|}
\hline 10 & & $\begin{array}{l}\text { The Equity crowdfunding platform with } \\
\text { companies that will be funded, are already in the } \\
\text { stage of selling their product, affecting you to use } \\
\text { an equity crowdfunding platform }\end{array}$ \\
\hline 11 & \multirow{2}{*}{$\begin{array}{l}\text { Success } \\
\text { Equity } \\
\text { Crowdfund } \\
\text { ing } \\
\text { Platform } \\
\text { Campaign }\end{array}$} & $\begin{array}{l}\text { The Equity crowdfunding platform with } \\
\text { companies that will be funded, have a good } \\
\text { economic potential, affecting you to use an equity } \\
\text { crowdfunding platform }\end{array}$ \\
\hline 12 & & $\begin{array}{l}\text { The time of the companies that will be funded has } \\
\text { established, affecting you to use an equity } \\
\text { crowdfunding platform }\end{array}$ \\
\hline 13 & \multirow[t]{3}{*}{$\begin{array}{l}\text { Intention to } \\
\text { Use }\end{array}$} & $\begin{array}{l}\text { Success equity crowdfunding platform campaign } \\
\text { will be more affecting you to use an equity } \\
\text { crowdfunding platform }\end{array}$ \\
\hline 14 & & $\begin{array}{l}\text { The initial investment amount, affecting you to } \\
\text { use an equity crowdfunding }\end{array}$ \\
\hline 15 & & $\begin{array}{l}\text { Mature project stage from companies that will be } \\
\text { funded on equity crowdfunding platform, } \\
\text { affecting you to use an equity crowdfunding } \\
\text { platform }\end{array}$ \\
\hline
\end{tabular}

\section{Hypothesis}

Firm age affecting the success equity crowdfunding platform campaign. Based on the previous research [8], firm age does not determine the success of equity crowd funding campaign. There are various conditions in accordance with the firm age, namely: new companies will invest more in $\mathrm{R} \& \mathrm{D}[9]$, and the new companies but innovative will be more developed compared to companies that have matured [10]:

1) The economic potential of firm affecting the success equity crowdfunding platform campaign. Based on previous research [8], It is known that there is no evidence of an economic potential of firm affecting to the success of the equity crowd funding campaign especially in relation to the decision to invest.

2) Success equity crowdfunding campaign affecting an intention to use equity crowdfunding platform. This hypothesis is a merging existing models in the study [8] and [7].

3) Minimum initial investment amount affecting an intention to use equity crowdfunding platform. Based on previous research [7], equity crowd funding which sets a minimum initial investment amount to allow more investors/donors to participate in the project. This is because the minimum initial investment has a significant impact on financing efficiency, an increase that can reduce costs, time and accelerate the success of project financing.

4) Mature project stage affecting an intention to use equity crowdfunding platform. Based on previous research [7], equity crowd funding which campaigns for projects with more mature stages of the project affects potential investors/donors to invest. For example, projects in stages that have made profit are more popular and preferred by investors.

\section{RESEARCH METHOD}

Based on acquired data, total 37 respondent $(37 \%)$ are woman and the rest 63 respondent $(63 \%)$ are man. With total 7 respondents (7\%) aged 17-22yrs, total 34 respondents (34\%) aged 23-28yrs and 59 respondents (59\%) aged above than 28 yrs. The highest respondent with total 52 respondent $(52 \%)$ is employed (figure 2 ).

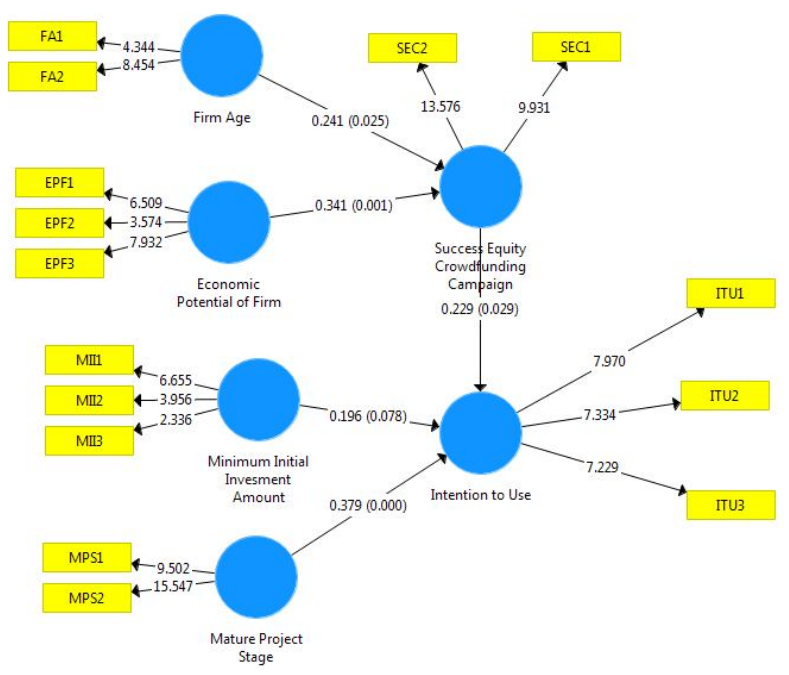

Figure 2.:Results Analysis

\section{A. Firm Age Variable}

CFA Analysis to this variable show good result with the loading factor higher than 0.5 . FA1 with loading factor 4.344 and FA2 with loading factor 8.454 .

\section{B. Economic Potential of Firm Variable}

CFA Analysis to this variable show good result with the loading factor higher than 0.5. EFP1 with loading factor 6.509, EFP2 with loading factor 3.574 and EFP3 with loading factor 7.932 .

\section{Success Equity Crowdfunding Campaign Variable}

CFA Analysis to this variable show good result with the loading factor higher than 0.5. SEC1 with loading factor 9.931 and SEC2 with loading factor 13.576.

\section{Minimum Initial Investment Amount Variable}

CFA Analysis to this variable show good result with the loading factor higher than 0.5. MII1 with loading factor 6.655 , MII2 with loading factor 3.856 and MII3 with loading factor 2.336 . 
Fauzan Nasafi et al., International Journal of Emerging Trends in Engineering Research, 8(6), June 2020, 2245 - 2248

\section{E. Mature Project Stage Variable}

CFA Analysis to this variable show good result with the loading factor higher than 0.5. MPS1 with loading factor 9.502 and MPS2 with loading factor 15.547.

First hypothesis stated (Table 2) Firm Age affecting success of equity crowdfunding campaign is acceptable. Which the longer the firm to be funded established will make the campaign of the equity crowdfunding be more successful.

Table 2: Summary of Tests

\begin{tabular}{|c|c|c|}
\hline Hypothesis & $\mathbf{P}$ & Remarks \\
\hline $\begin{array}{l}\text { Firm Age affecting success of equity } \\
\text { crowdfunding campaign }\end{array}$ & 0.025 & Significant \\
\hline $\begin{array}{l}\text { Economic Potential of Firm affecting } \\
\text { success of equity crowdfunding } \\
\text { campaign }\end{array}$ & 0.001 & Significant \\
\hline $\begin{array}{l}\text { Success of Equity Crowdfunding } \\
\text { Campaign affecting society intention } \\
\text { to use the equity crowdfunding } \\
\text { platform }\end{array}$ & 0.029 & Significant \\
\hline $\begin{array}{l}\text { Minimum Initial Investment Amount } \\
\text { affecting society intention to use the } \\
\text { equity crowdfunding platform }\end{array}$ & 0.078 & $\begin{array}{l}\text { Not } \\
\text { Significant }\end{array}$ \\
\hline $\begin{array}{l}\text { Mature Project Stage affecting society } \\
\text { intentionto use the equity } \\
\text { crowdfunding platform }\end{array}$ & 0.000 & Significant \\
\hline
\end{tabular}

Second hypothesis stated Economic Potential of Firm affecting successful campaign of equity crowdfunding is acceptable. Which the higher economic potential of the firm to be funded will make the campaign of the equity crowdfunding be more successful.

Third hypothesis Mature Project Stage affecting Jakarta's society intention to use the equity crowdfunding is acceptable. Which the more mature the project stage been through by the funded firm will be more affecting Jakarta's society to use the equity crowdfunding platform.

Fourth hypothesis Minimum Initial Investment Amount affecting Jakarta's society intention to use the equity crowdfunding is unacceptable. Which with minimum initial investment amount option does not affect Jakarta's society to use the equity crowdfunding platform.

Fifth hypothesis Success Equity Crowdfunding Campaign affecting Jakarta's society intention to use the equity crowdfunding platform is acceptable. Which the more success the campaign established will be more affecting Jakarta's society to use the equity crowdfunding platform.

\section{CONCLUSION}

Conclusion from the research conducted are as follows: (1) Firm Age affecting successful campaign of equity crowdfunding. Which the longer the firm to be funded established will make the campaign of the equity crowdfunding be more successful; (2) Economic Potential of Firm affecting successful campaign of equity crowdfunding. Which the higher economic potential of the firm to be funded will make the campaign of the equity crowdfunding be more successful; (3) Mature Project Stage affecting Jakarta's society intention to use the equity crowdfunding. Which the more mature the project stage been through by the funded firm will be more affecting Jakarta's society to use the equity crowdfunding platform; (4) Minimum Initial Investment Amount does not affect Jakarta's society intention to use the equity crowdfunding. Which with minimum initial investment amount option does not affect Jakarta's society to use the equity crowdfunding platform; (5) Success Equity Crowdfunding Campaign affecting Jakarta's society intention to use the equity crowdfunding platform. Which the more success the campaign established will be more affecting Jakarta's society to use the equity crowdfunding platform.

\section{REFERENCES}

[1] P. Belleflamme. T. Lambert. \& A. Schwienbacher. (2014). Crowdfunding: Tanning the right crowd. Journal of business venturing, 29(5), 585-609. https://doi.org/10.1016/j.jbusvent.2013.07.003

[2] T. Hellmann, (2007). Entrepreneurs and the process of obtaining resources. Journal of Economics \& Management Strategy, 16(1), 81-109.

[3] J. Hemer (2011). A snapshot on crowdfunding (No. R2/2011). Working papers firms and region.

[4] A. Y. Nugroho \& F. Rachmaniyah,. (2019). Fenomena Perkembangan Crowdfunding Di Indonesia, EkoNiKa, Vol. 4, No. 1, 34-46 https://doi.org/10.30737/ekonika.v4i1.254

[5] D. Freedman, \& M. R. Nutting, M. R. (2015). A brief history of crowdfunding. Including Rewards, Donation, Debt, and Equity Platforms in the USA.

[6] C. L. Massolution, (2015). Crowdfunding industry report. See http://reports. crowdsourcing. org/index. php.

[7] Li, Y., Cao, H., \& Zhao, T. (2018). Factors Affecting Successful Equity Crowdfunding. Journal of Mathematical Finance, 8(02), 446.

[8] Correia, S. I., Sousa, M., \& Brandão, E. (2019). Drivers of fundraising success in equity crowdfunding. Available at SSRN 3354210.

[9] Czarnitzki, D., \& Kraft, K. (2004). Firm leadership and innovative performance: Evidence from seven EU countries. Small Business Economics, 22(5), 325-332.

[10] Coad, A., Segarra, A., \& Teruel, M. (2016). Innovation and firm growth: Does firm age play a role?. Research Policy, 45(2), 387-400.

https://doi.org/10.1016/j.respol.2015.10.015

[11] E. Mollick, "The dynamics of crowdfunding: An exploratory study," J. Bus. Ventur., vol. 29, no. 1, pp. 1-16, 2014, doi: 10.1016/j.jbusvent.2013.06.005.

[12] A. K. Agrawal, C. Catalini, and A. Goldfarb, "The Geography of Crowdfunding," Crowdfunding Entrep., pp. 31-60, 2020, doi: 10.4324/9780429319785-5.

[13] Gerber, Hui, and Kuo, "Crowdfunding: why people are motivated to post and fund projects on crowdfunding platforms, Northwestern University Creative Action Lab, Sheridan Drive," 2011, [Online]. Available: https://pdfs.semanticscholar.org/c1e2/a1068f0af1c3120 c62be5943340518860ecb.pdf.

[14] A. K. Agrawal, C. Catalini, and A. Goldfarb, "Some Simple Economics of Crod," J. Chem. Inf. Model., vol. 53, no. 9, pp. 1689-1699, 2013, doi: 10.1017/CBO9781107415324.004. 